\title{
FRONTLINE
}

\section{The making of Ophir - Bougainville stories and silences \\ An exploration of the documentary}

\begin{abstract}
This article focuses on the making of the award-winning film Ophir in the context of issues relevant to journalism and documentary production. It explores how a partnership of filmmakers, scholars and Bougainvillean community leaders worked to create a documentary that goes beyond bare facts to create deeper meaning. Based on an interview with one of the filmmakers Olivier Pollet, it discusses issues of archival research, gender, distribution and language. It raises ethical questions about how mining company Rio Tinto used an anthropologist to produce covert corporate intelligence in the 1960s. Through a discussion of the work of independent investigative journalist Antony Loewenstein, it considers how recent Australian aid policy was used to shape public debate about options for Bougainville. It highlights the importance of supporting grassroots storytelling that penetrates distorted mainstream media narratives, especially at a time of shifting geopolitical interests.
\end{abstract}

Keywords: anthropology, aid, Australia, $\mathrm{BCL}$, Bougainville, decolonisation, documentary, environment, film, foreign policy, empowerment, Frontline, gender, geopolitics, independent journalism, Indigenous, land rights, mining, Oceania, Ophir, Pacific, Pacific history, Panguna, Papua New Guinea, Rio Tinto, storytelling

\section{WENDY BACON}

Frontline Editor, Pacific Journalism Review

NICOLE GOOCH

Assistant Editor, Pacific Journalism Review

-HE lack of coverage by the Australian media of the Pacific region has been well documented (Duffield, 2020; Nash \& Bacon, 2003; Watkins, 2019). At the same time, the influence of the foreign affairs establishment 


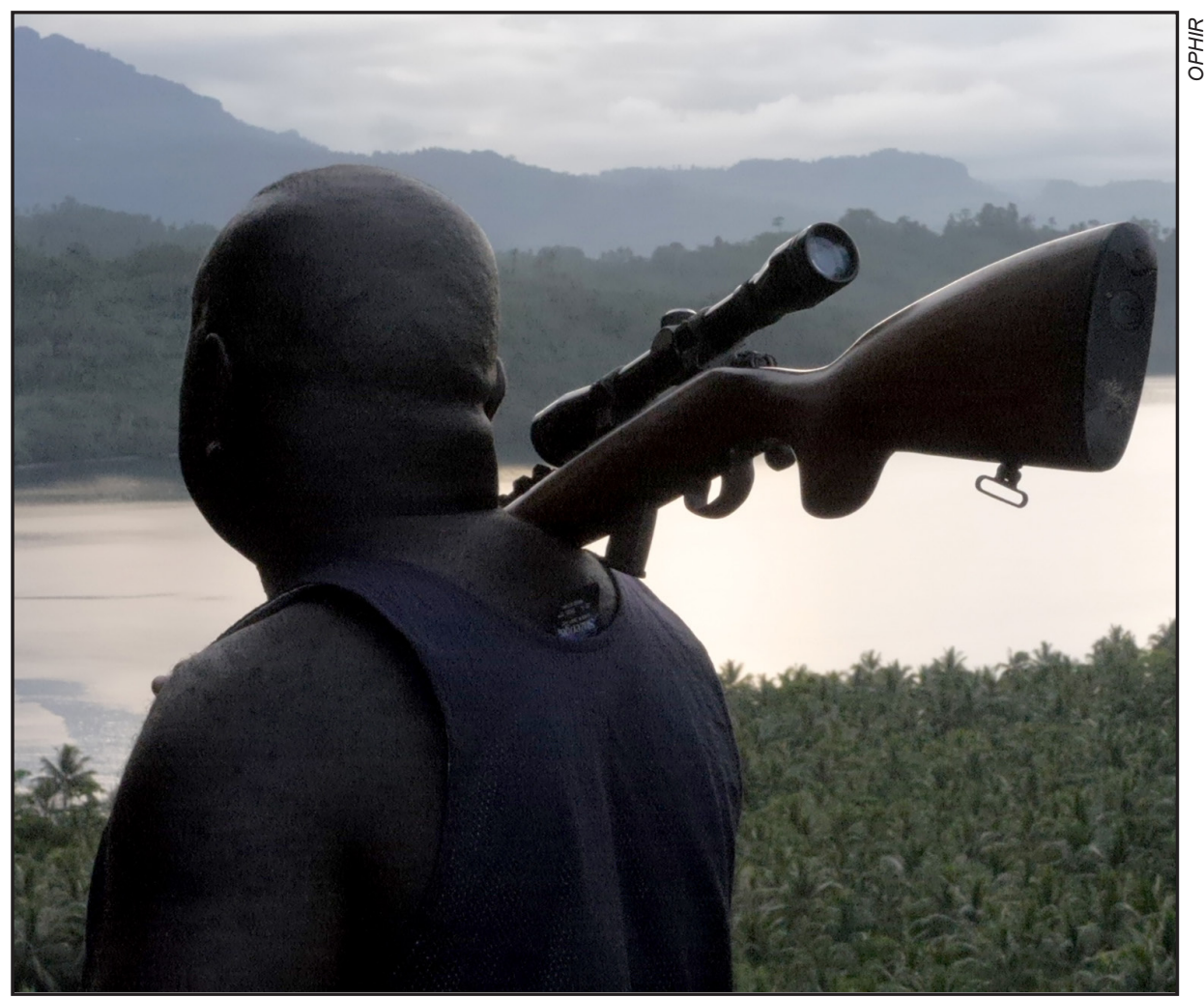

Figure 1: A decade-long war in Bougainville, 'The Crisis', as the period of conflict is known, began in 1988 and cost up to 20,000 lives.

on the framing of media coverage has increased due to strong links between the Australian government, academic and think tank organisations. Within this context, the role of freelance, independent and Pacific journalists and documentary makers in empowering local voices and challenging official narratives is crucial, particularly at a time when there is a new emphasis on strategic power plays in the so-called Indo-Pacific region, while Oceania also faces the challenges of decolonisation and the climate emergency.

In her contribution to Frontline in 2020, Belinda Lopez explored how 'interdisciplinary research' — such as anthropology and history - might intersect with journalism as a means to understand and challenge existing gaps in translation, or 'silences' about West Papua in the past and present. She drew on what the Haitian anthropologist Michel-Rolph Trouillot (1995) describes as the production of silences in the historical narrative. He argues that such silences are about power-they do 'not require a conspiracy, not even a political consensus. Its roots are structural' (Lopez, 2020, p. 201). Lopez was in West Papua in August 2019 when large protests broke out against the oppressive rule of Indonesia. She saw this as an opportunity. 
I realised that I might be able to create a long-form journalism project that could explore the roots of this discontent, not in a paragraph aside but as a framing question about the recent and not-so-recent past. I felt an urgency in doing so, given the media portrayals and censorship of Papuans, community violence and heavy state response to the uprisings. (Lopez, 2020, p. 201)

The result was a radio documentary \#Illridewithyou, West Papua (2020) and a long form article for ABC Radio National (2020).

In 2004, David Robie reviewed Mothers of the Land: The birth of the Bougainville Women for Peace and Freedom, which included accounts by 11 women of their struggle for independence and against the blockade imposed by the Papua New Guinea Defence Force (PNGDF), for Pacific Journalism Review. He described the blockade as a 'shocking crime against humanity, a sort of genocide while the rest of the world turned its backs on the suffering Bougainvilleans. During this time, PNGDF forces strafed villages, raped, mutilated and executed both women and men, and rounded up people, forcing them to stay in "care centres" as internal refugees' (Robie, 2004, p. 226). Robie then asked,

Why did the world community allow this to happen? Contrast the global silence over these atrocities with the saturation media coverage and outrage over the killing and mutilation of four American security men in Fallujah, western Iraq in mid-April, a week before the launching of this book in New Zealand. (p. 226)

In considering the similarities and relationship between history and journalism, Nash also discussed how contemporary journalism can inject fresh meaning into history and expose past silences produced in earlier historical accounts (Nash, 2016, p. 145). These issues are relevant to this edition of Frontline in which we explore the research and production of the documentary Ophir that was released in 2020 .

Ophir is the name sometimes used for Bougainville, the main island of the Autonomous Region of Bougainville in eastern Papua New Guinea, in the Solomon Sea. In 2019, almost 98 percent of its citizens voted for independence from PNG after a decade-long war. 'The Crisis', as the period of conflict is known, began in 1988 and cost up to 20,000 lives. The roots of 'The Crisis' go back to the 1960s when Conzinc Rio Tinto Australia (CRA) began to develop infrastructure for a copper and gold mine at Panguna (Cass, 2014; Denoon, 2000). Despite protests and claims of independence, the company seized land from local owners and began to operate the copper and gold mine in Panguna in 1972.

The mine caused a massive environmental and social catastrophe, and eventually sparked the war when the PNGDF intervened to crush uprisings against 


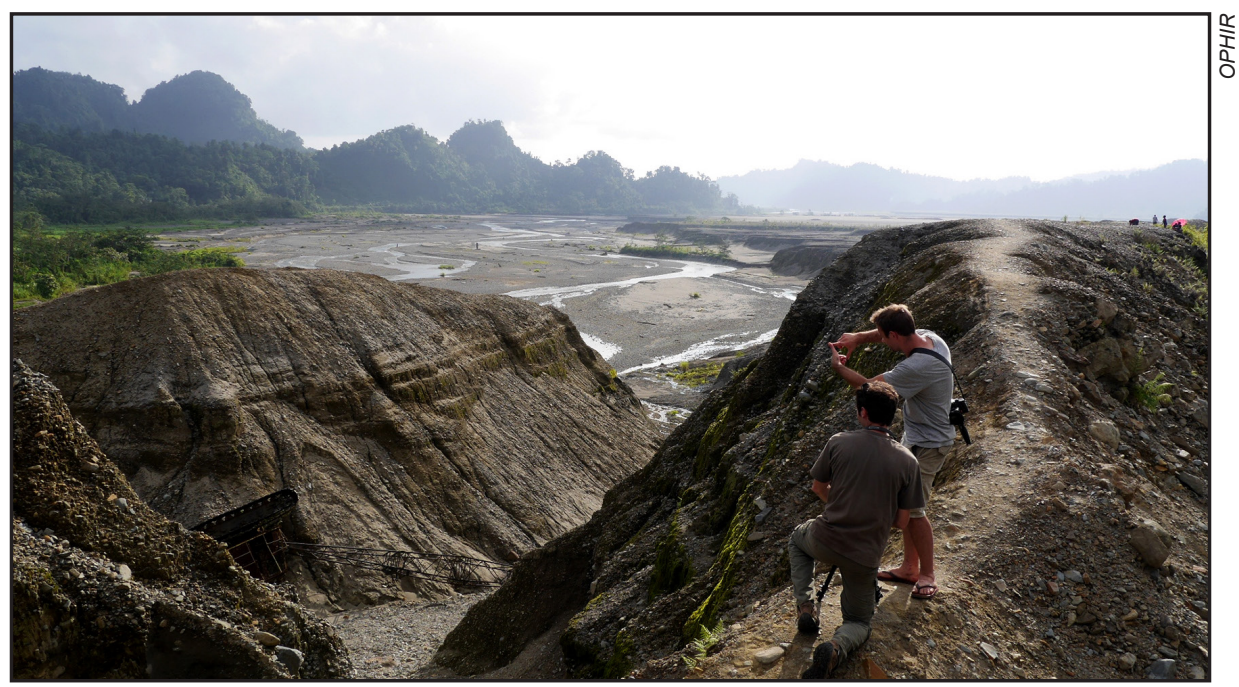

Figure 2: Directed by two French filmmakers, Olivier Pollet and Alexandre Berman, Ophir is a seven-year collaboration between independent freelance filmmakers, local partners and a scholar whose research has focused on Bougainville.

it. The BCL mine was shut down in 1989 but by then the conflict had morphed into a war for independence.

Ophir has already won several international awards, including the Grand Jury Prize at the FIFO - the International Documentary Film Festival of Oceania, held in Tahiti in 2020 - and the Grand Prix Rigoberta Menchù, named after the Nobel Prize laureate at the Montreal First Peoples Festival Présence Autochthone. It screened at Academy Award qualifying festivals DocEdge and the Durban International Film Festival, and will have screened in 80 film festivals in more than 40 countries by the end of the year. As we will see, this project was also inspired by a desire to break through silences and misunderstandings about the history and current situation in Bougainville.

Ophir is a seven-year collaboration between independent freelance filmmakers, local partners in Bougainville and a scholar whose research has focused on Bougainville. It is directed by two French filmmakers, Olivier Pollet and Alexandre Berman. Bougainvillean Nathan Matbob was assistant director and his wife, Theonila Roka Matbob, currently the Minister for Education in Bougainville, was a researcher on the film and part of the core production team. Professor Kristian Lasslett, head of the School of Applied Social and Policy Sciences at the University of Ulster, is one of the producers of the film, and the author of State Crime on the Margins of Empire, Rio Tinto, the war on Bougainville and resistance to mining (Lasslett, 2014). The film was produced with the support of Ulster University, France Télévision and Centre National Du Cinéma et de L’Image Animée. 
This contribution to Frontline is based on a dialogue between the editors and co-director Olivier Pollet about the approaches used in the making of Ophir. In the context of discussing documentary and other research about Bougainville, we also refer to the work of independent journalist and documentary maker Antony Loewenstein, whose book Disaster Capitalism: Making a Killing out of Catastrophe and film of the same name include an investigation into connections between foreign aid and mining in PNG with a strong focus on Bougainville (Loewenstein, 2015; Loewenstein \& Neureiter, 2018).

Lopez, Pollet and Loewenstein's contributions is best thought of as bodies of work across different media. Ophir includes the French national television hour-long version, The Panguna Syndrome (Berman \& Pollet, 2017), and The Colonial Syndrome (Berman \& Pollet, 2020), a multimedia educational website that includes over 30 short films and extended interviews recorded during the period of the film's production, and archival documents shedding light on the history and mechanisms of past and present colonialism in Bougainville.

Pollet began making films in the Pacific 11 years ago. His first documentary film Canning Paradise was also based in Oceania. Canning Paradise dealt with the consequences of globalisation, that led to the delocalisation of the South Asian fishing industry in PNG in order to exploit the last remaining healthy stocks of fish. It tracked the struggle of local peoples to protect their way of life against the land grabbing and politics that encouraged the forced industrialisation of the country.

\section{From Canning Paradise to Ophir}

We began by asking Pollet if there was any link between the two projects. He explained that relationships he formed during the Canning Paradise project led to the local collaboration that is at the core of Ophir.

Pollet: This film is very closely linked to my previous works-Canning Paradise (2013) that I worked on from 2010 to 2012 and When we were Hela (2014) — which was also made in PNG. Although different in its form to Canning Paradise, Ophir is almost like an extension of it in many ways.

While I was working on the distribution of Canning Paradise in 2013, I was invited to show the film at a research training colloquium organised by the State Society and Governance in Melanesia Programme (SSGM) in the College of Asia and the Pacific at the Australian National University (ANU) in Canberra. During the colloquium, I attended a session on Bougainville and mining. I was shocked by the content of the seminar. The discussion seemed to assume that Bougainville would find independence through the return of mining and the return of $B C L$ and Rio Tinto to Bougainville. What I was hearing in Canberra was the absolute opposite of what I was hearing from the communities still living with the lasting legacy of the mine. I was also surprised that there was little

154 PACIFIC JOURNALISM REVIEW 27 (1 \& 2) 2021 


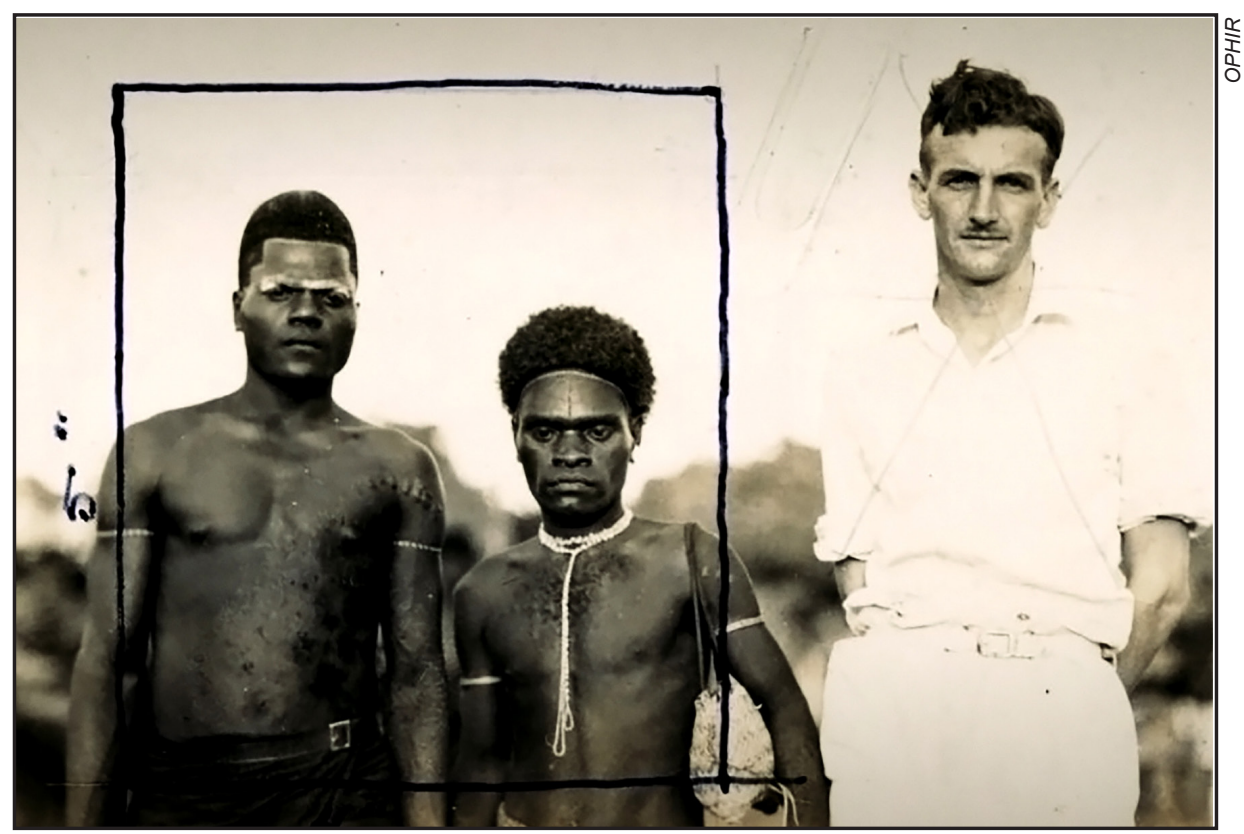

Figure 3: A technique in which the words of Bougainvilleans are juxtaposed with the historical archival material sets up the narrative is used throughout the film.

mention in the session of the many dead or the lasting trauma that came from the Bougainville conflict. I felt I needed to take this further.

During the filming of my two earlier films, I had formed some strong relationships with Bougainvillean students, including Nathan Matbob. Nathan got married to an extraordinary woman from Bougainville named Theonila Roka Matbob who was elected to the Bougainville Parliament and is now the Minister for Education. They live in Makosi village, a place located in the upper tailings area and devastated by the Panguna mine. So I reached out to them to find out what they thought about how people viewed the situation in Bougainville. They told me that none of the villagers really knew about the discussions to reopen the mine. Yet what I had heard at the ANU during my two visits would have given me the impression that everyone was all in favour of the return of the reopening of the mine and that a new Mining Act had been developed that would protect the rights of the customary landowners.

The idea for the film originated through this contradiction. So we formed a team with my co-director Alexandre Berman and a core group of Bougainvilleans. This collaboration lies at the heart of the project.

\section{The world needs to know that this land has been redeemed}

In its first moments, Ophir firmly establishes the deep spiritual connection between the people of Bougainville and their land. A man who has lost his mother, 
father and big brother during the Crisis says, 'We have painted this land with blood and we don't know what more we have to tell the world. The world needs to know that this land has been redeemed'. Children are filmed watching an old video about their people's fight for their land. A woman's voice is heard:

\author{
Daughter Bougainville they diagnosed \\ Copper and Gold she full \\ Skilful as gynaecologist \\ Operating pregnant woman \\ They extracted her baby \\ The birth of world class mine. (Tahun,1998)
}

The scene shifts to a Bougainville Copper Ltd (BCL) corporate video from the 1970s. A white family is on a plane en route to PNG. They travel by road from Arawa to Panguna. The sound track explains the geographic dimensions of Bougainville but no local people are seen. Then we switch to archival ABC news footage from the 1960s. A reporter directly asks a Bougainvillean man what he will do when his land is taken without permission. He replies, 'We are going to hold our lands - it's better for us. The government will have to kill us to take our lands.' A mine manager says, 'I think they're naturally suspicious because they don't understand our way of life ... it's the problem of the unknown that worries them.' The implicit racism and arrogance of the white man contrasts with the evidence of Bougainvilleans' strength of feeling about their land and their resistance to its occupation.

This technique in which the words of Bougainvilleans are juxtaposed with the historical archival material sets up the narrative and is used throughout the film. It allows the audience to compare the perspective of local people on the ground in both earlier and contemporary times with the perspective of those aligned with corporate and state interests. There is no need for a voiceover. Later in the film, paragraphs from a secret corporate report and other documents appear on the screen. The documents are now available on The Colonial Syndrome website (www.colonialsyndrome.org). We asked Pollet about the archival research process.

Pollet: Even before we began filming, we did two years of pure research, collecting all the film and other documentary archives including colonial records so that we would be prepared and have them with us when we were talking with communities all over Bougainville.

The only time that we were pressured while making the film was in having sufficient funds to finance the film archives. This is one of the biggest problems in making documentaries nowadays. While maintaining archives has a real cost, most companies or institutions take no account of whether you are a small independent production or a Hollywood 
blockbuster. This results in a situation in which only very big production companies can cover the costs of historical material-and thus tell'history'. In our case, we were forced to produce a shorter television version of our project, called The Panguna Syndrome-solely for the purpose of starting to cover these enormous archival costs, the biggest budget line of the film. The Panguna Syndrome ended up being a nominee in 2017 for the Albert Londres Prize, France's most prestigious award for investigative journalism.

In explaining how we gathered the archival material, I need to introduce the role of Professor Kristian Lasslett, whose work informed our research and who became a producer of the project. He is head of the School of Applied Social and Policy Studies at the University of Ulster. Kristian spent more than 15 years collecting records for his doctorate and then for the book State Crime on the Margins of Empire: Rio Tinto, the War on Bougainville and Resistance to Mining (Lasslett, 2014). He applies an institutional power framework and rather than seeing the state and corporate actors as independent of each other, explores the social relations between them.

He accessed records filed in a case by 10,000 Bougainvillean plaintiffs against Rio Tinto in the United States in which it was alleged that the mining company was complicit in war crimes and had violated customary international law, including the right to life and health (Lorne, 2013). Although the case was ruled to be outside the scope of US law, the court documents were an invaluable source of information. There was also another court case involving Rio Tinto about insurance in Melbourne. We scanned everything in his boxes so we could share it with local people when we went to Bougainville.

Among those documents was a secret report prepared for CRA by Professor Douglas Oliver. For people who know about the Pacific, Oliver is regarded as something like the godfather of Pacific anthropology. If you ask people about Bougainville, they often refer to Black Islanders: $A$ Personal Perspective of Bougainville (Oliver, 1991) which is his personal account of what occurred on Bougainville. In the late 1960s, he was appointed professor of anthropology at both Harvard and the University of Hawai'i.

In Black Islanders, Oliver acknowledges his work for the company:

From 1968 to 1978 I was employed by Bougainville Copper Ltd as a part-time consultant, to advise the company on how to conduct their operations so as to shield Bougainvilleans as much as possible from the harm that inevitably accompanies such mining. During that period, I visited the island once or twice a year. In addition, I organised and supervised a research programme designed to provide the province's leaders with information relevant to their 
planning for the populace's social and economic well-being. The programme was sponsored by the University of Hawai'i and included scholars from that institution, from the Australian National University, from New Zealand's Canterbury University, and from the University of Papua New Guinea. It was financed in large part by Bougainville Copper Ltd, which, however, exercised no control over it. (Oliver, 1968)

We obtained the original confidential report. There were some later secret ones but unfortunately we still don't have access to them. What we believe the document shows is that anthropology can be used as a weapon of war. In this case an anthropologist turns against the populations he was studying and with whom he was building relationships. The existence of these confidential reports have not been known to many people, including Bougainvilleans themselves.

The secret report recommends strategies that you would not expect to see from a research anthropologist. You can access the full report on The Colonial Syndrome. Oliver explains to Rio Tinto that he has had talks with John Crawford about establishing a whole department at ANU that would be sponsored by Rio Tinto. At this stage, we don't know if the talks were as advanced as he asserted or if Crawford was enthusiastic. The irony for me is that our whole project started in the John Crawford room at ANU. But when you attend these research meetings, you do have a feeling that there are strong Australian government, including intelligence, interests influencing the agenda. It used to be called State, Society and Governance in Melanesia programme but is now called the Department of Pacific Affairs.

The way Ophir's directors use the confidential Oliver report provides a good illustration of how different parts of the project work together. In the film, small sections are read from the report juxtaposed with interviews with archival visual images or interviews with Bougainvilleans about the impact of the loss of land. By visiting The Colonial Syndrome, those who are interested can get a detailed glimpse into how this distinguished anthropologist conducted his research according to 'terms of reference' set by Rio Tinto. Oliver certainly understood the deep significance of land to Bougainvillean people and recognised that the seeds of resistance existed. He even recommended that a certain amount of organised opposition may advantage Rio Tinto so long as it is 'within bounds' because if not restrained it could be 'catastrophic'. He uses an almost casual tone in his detailed recommendations to CRA for how it can best handle 'external relations' at its planned mine. He recommends that CRA hire 'agents' to conduct its 'Intelligence' operations and that the company should disguise aspects of its 'relationship with the PNG administration'. It seems unlikely that the Bougainvilleans, administration staff, academics and students that he inter- 
viewed were aware of the purpose of his research. These days, much universitybased research is commissioned by external partners and although the terms of agreements are not public, most researchers declare funding sources. But this is different from covert research. The contents of Oliver's report are disturbingly duplicitous (such as a preference to verbally communicate some of his recommendations). In relation to women, Oliver advises that women who have been 'relieved of their garden work and other chores associated with village life' (in other words excluded from their land) will have 'much mischief-inviting time on their hands unless a substitute activity is provided for them' such as 'sewing classes or English lessons, etc' (Oliver, 1968, p. 60). Otherwise, he warns, they will become 'trouble-centres' (p. 60). Has there been any public discussion of the role of Rio Tinto's use of undercover research and in particular the role of Douglas Oliver? What has been the reaction of anthropologists to the use of the report in the film?

Pollet: I spoke to anthropologists at the RAIO Film Festival (festival. raifilm.org.uk) and will do so again in late October at a conference of 800 anthropologists from around the world. It was explosive for them - the collusion between the world of academic, intelligence, etc. which goes beyond the classic 'funding issue' for research.

We do know as a result of a footnote in Glynn Cochrane's book about the use of anthropology in the mining industry that Oliver regarded his reports as 'highly confidential' and wanted them to remain secret and unpublished. He told Cochrane in 2000 that a complaint had been lodged by the American Anthropologist Association alleging that his failure to make his research public was a breach of ethics but that it was dismissed. This association provision was introduced at the time of the Vietnam War to prevent anthropologists becoming clandestine researchers. (Cochrane, 2017, p. 27)

\section{What are the biggest impressions or experiences that you as filmmakers took away from this project?}

Pollet: The feeling of touching history. We had done films before about natural extraction, about exploitation, but in this film we had the feeling that we were touching the DNA of the system of Western nation building as it is imposed on traditional societies.

The process of filming was organic and we didn't want to set any limits. The film was shot over two years following the initial two years of research. We wanted the film to be about'experience' and we looked for the 'echoes of experiences' in order to shed light on what colonialism means and does both collectively and individually. How it affects identities, views of oneself, beliefs and more, but doing so in a way where we were not making a film about people, but 'with them', so they could 
claim that space and freedom of expression both in the film and in the multimedia platform.

There are 19 distinct languages in Bougainville. We shot in four different languages-we wanted people to speak in whatever language they wished: English, Tok Pisin, Nasioi and Avaipa. The transcription and translation took a year-there were thousands of words! Sometimes you would reach a community that all of a sudden started using another language, which meant the people we were working with could not fully understand what was being said.

As we progressed, we realised it wasn't necessarily going to be a film about a mine. The testimonies were taking us in places much deeper than that as they were shedding light on the system behind it, the system of thought that allowed it, and which still prevails nowadays all around Papua New Guinea, decades after its roots and ideologies were planted and grew.

We were disturbed by the horrific losses. Ten percent of the population in terms of scale, 20,000 people. Imagine if it was in our own country. This doesn't take into account the large number of people displaced or sent to concentration camps (then called 'care centres') around the island.

The scale of the environmental damage is also such that it is even hard to capture in pictures. You are in the original Dapera village where you know you are standing above the original village. Before you there are entire valleys that are built of rocks and it looks like an original landscape but it is not. All the mountains you see around you were all formed by the dumping of waste from the mine in the valley. And you are separated by 130 metres of waste rock between the ancestral village under your feet and the new houses built on top, as close as possible where their ancestors lived. It feels surreal. As for the tailings, they were dumped straight into the river, making it rise by 30 metres in some parts. It's very hard to picture it.

People were extremely happy to share their experiences with us. What I found was that the same words that I had read in documents also came from entirely different people. Often we heard the same expressions, repeated dozens of times in interviews with different people. Sometimes we heard people using the same words, almost word for word, in the north of the island and the south of the island, to describe their experience.

What is interesting is that now that the film has been released, we have been contacted by First Nations people in the north of Canada who have told us that portions of the film mirror their experience word for word. I did not expect this. I hope what this means is that we have captured the processes of 'colonialism', yes it happens in Bougainville but it happens in so many places. For instance, our film was selected as part of the main 
line-up competing at the biennial RAI Film Festival this year, organised by the Royal Anthropological Institute in England. At the festival I discovered the remarkable first feature length film made in Inuktitut, by a famous Inuit filmmaker Zachiaras Kunuk. The film is titled One Day in the Life of Noah Piugattuk and relates events and dialogues that occurred in Canada in 1964, when the Canadian government was forcing Indigenous populations to settle into towns and accept 'the new way'. There are portions of dialogues that we found were repeated word for word by various communities in Bougainville. One of these communities even re-enacted for us events that also occurred in 1964 on their land. This was extremely surprising for us, to uncover how similar in some ways the colonial experience has been for very distant communities in the world.

Even though you did as much documentary research as a conventional investigative journalist might do, the film has a very poetic feel. Can you comment on that?

Pollet: We could have done the film very differently, very journalistically but poetry allows you to go directly to the heart of experience. There is the saying: a picture speaks more than a thousand words. Poetry for us was similar. It allows you, in a much shorter way, to go to the heart of an issue, without having to explain all the details that led to a feeling, because it speaks for itself-it is reflective, and the words have already been very carefully selected by the author of the work, and in many ways allows audiences to go beyond, much quicker than a simple listing of facts or events and their consequences, in terms of narration. But it was also important to start by researching the records so that we could free ourselves for the interviews as we travelled through Bougainville. People didn't have any access to documents so we had them available during the filming but we also have them published on The Colonial Syndrome website. People can watch the film as an introduction and there is more if you want the hardcore investigative experience. As we were filming, we knew something wouldn't make it into the film but we knew it could have relevance. So we used them as short vignettes on The Colonial Syndrome for those wanting deeper, more precise accounts as a way of explaining collective experience.

As we started to talk to people, sometimes they brought us more documents that included poetry. One such moment was when we were brought excerpts of poems from a collection called An Anthology of Crisis Poetry from Bougainville by Matubuna Tahun. It was brilliant and at the same time surprising - we had already read these poems during our research, as we had managed to get our hands on this book. And we could then also provide the whole collection to villagers who only had excerpts of the book. Before starting filming, we had the intuition that we should somehow use these poems, and this was confirmed by the fact that these poems were indeed very important for some communities. 
People were not reluctant to talk, they were very eager to talk. The problem with media and the portrayal of remote communities is that mainstream media do not have the resources to travel to remote communities. Therefore they only have access to the centres of powerwhere the towns are, and it is a few men in the towns who then become the voices of history. This is very problematic. It always ends up being the same voices. We wanted to take an open-ended approach and this led to us having a huge amount of material.

There is also the issue of the way you work with communities. You can't just go and show up at their doorstep and expect them to tell their stories. You need to let them know that you are coming and then ask if they are interested in sharing their experiences. You can only do this with the luxury of time; coming back several times is also important. You would get something very different if you were in a rush. You need to build trust and understanding.

One of the most important people that we worked with was Dr Ruth Saovana who was travelling to communities explaining the new Mining Act that had been passed by the Bougainville government. We followed Ruth, who was then visiting communities all around Bougainville in order to make them aware of potentially extremely dangerous provisions within the new mining law that people were not aware of, as no one, or very few had read or had access to the law. These provisions basically curtail any opposition to mining by imposing extraordinarily hefty fines and jail terms, even for very minor acts such as not revealing one's name and address to a mining officer (that would be a year in jail). And this becomes even more problematic in a place which traditionally did not have jails before the white people came-for practical reasons-so as not to exclude dangerous individuals from communities and sever the bond that unified everyone, with the fear that they could become even more dangerous when put in isolation. It is parting from traditional systems of compensation who have been around for millennia. The meetings held by Ruth were truly extraordinary. They allow audiences to witness consultations in action-and see how people express their concerns. It draws attention to the effects of the legalisation of dispossession, and how this process can be used against traditional communities. If you interfere with the operations of a bulldozer for instance, it's five years in jail and a US\$75,000 fine. People need to know this, but I fear today many are still not aware of it.

At the beginning of the film, the words appear on the screen: 'In the South Pacific lies the land of Ophir, today known as Bougainville Island. This land is primarily owned by women'. There are a number of strong women in the film including Ruth Saovana who are playing a leadership role in their communities. On the other hand, although several women have been elected previously, we 


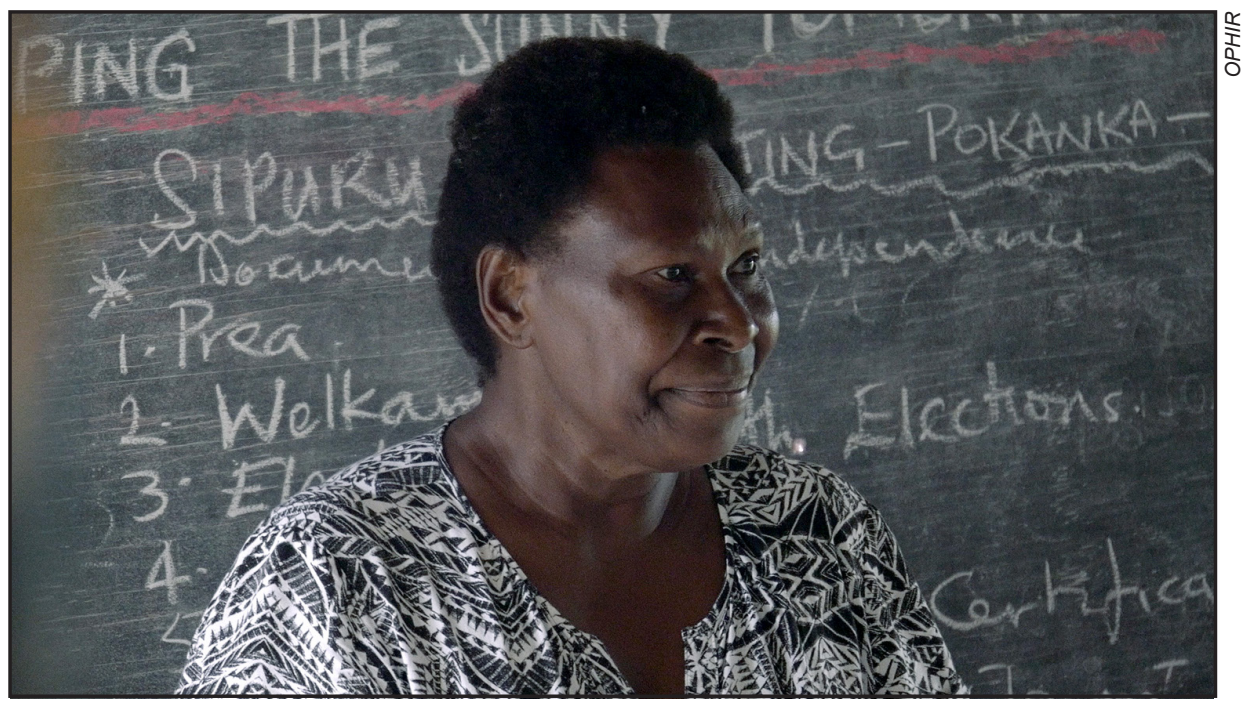

Figure 4: There are a number of strong women in the film including Dr Ruth Saovana who are playing a leadership role in their communities.

know that there are currently no women in the PNG National Parliament. Could you comment on the issue of gender and how it arose during your filming?

Pollet: Actually, gender was a big challenge during the filming process. When you go to the village, the men are the ones who sometimes prevent the women from talking. But it wasn't always this way. Every single decision involving land in Bougainville was made by women. In the 1960s, women were leaders in the protest against Rio Tinto ... But now there is a power imbalance. There are very few women in Parliament in the whole of PNG. There is a concentration of power in the hands of a few men and it is always a pocket of men who do their deals. The problem is that when people go to Bougainville, they can be persuaded by these same men and are left with the impression that these men represent far more people than they actually do. The men's views then get reported outside Bougainville.

But there is change. Theonila Matbob, who was a researcher on the film, got elected aged 29 to Parliament, beating 14 men. She is one of two female cabinet ministers in the Autonomous Government of Bougainville.

One of the strengths is that there is a diverse range of people in the film. Can you explain to us the role of the man who appears at the beginning of the film and again at the end. It seemed to us that his words were very important in creating a key message of the film: 'The foreigner. The problem was created in his own land. And when he came into Bougainville, his problems became the problem of the Bougainville man.' 
Pollet: Blaise Iruinu was one of the right-hand men of the Bougainville revolutionary leader Francis Ona. He is a philosopher. His knowledge was not built in Western universities. It was built on observations of what he saw happen on his land. In the 1980s, he looked after the BCL cinema in Panguna and now he is very involved in peacebuilding around Bougainville. He is also at the head of one important Me'ekamui faction, the traditional government that you have in Bougainville. He is well respected and an important intellectual.

This is the first time that he had talked about his experiences and what the war was about. We filmed with him for 16 hours over 4 sessions.

On one occasion, we filmed for three hours and then he said that he would come back because he needed to bring documents, some that he had written himself. He kept them to make sense of what had occurred. He broke down the mechanisms of colonialism, its history from a Bougainvillean perspective. We have published his testimony-almost uncut-on the website (in three parts of 40 minutes each or so) and we are considering turning it into a book. It may sound a little bit dry, but it is important.

His knowledge is from an Indigenous vision of the world built on experience and deductions. In the film he acts as a kind of intermittent narrator, although we did not plan for that. This is why we opened and ended the film with him. At the end, he addresses people outside and says, 'You may not believe everything that I am telling you but this is how I see the world.' If we are to understand the colonial experience and the need for decolonisation, we need to listen to these voices who may not have the biggest credentials or come from 'prestigious' universities elsewhere. They need to emerge and become visible, be read and understood.

\section{Film distribution}

It was important for co-directors Pollet and Berman that the film was shown first in the Pacific. It received the top prize-Grand Prix du FIFO, at the Festival International du Film Documentaire Océanien in Tahiti in February 2020. 'This film won unanimous support. Everyone was moved. It describes colonisation in a certain way with very strong emotions. The directors managed to get their hands on very special documentation,' said Eric Babier, chair of the jury as he announced the Grand Jury Prize winner. All members of the jury were from different Pacific Islands, and included Kanaky New Caledonia playwright Pierre Gope, who told Pollet the film spoke on the issue of colonisation and mining in a way rarely seen.

Ophir is also scheduled to be shown in Kanaky New Caledonia at the Ânûû-rû âboro Film Festival in October 2021, on the eve of the country's third and final 
referendum on independence within the framework of the Noumea Agreement. However, in the meantime, trying to get the film distributed-and in particular through the islands of Oceania - has been particularly difficult because of the COVID-19 pandemic.

\section{Have you had much feedback from people in Bougainville?}

Pollet: Yes and no. It has largely been complicated by COVID. Of course, we have sent the film and it is currently largely circulating informally on Bougainville but it's different to what we had envisioned. We wanted to do a film tour in Bougainville although this has been made impossible with the health situation. But it is very much something that we would like to return to, perhaps next year. Even sending the film via USB has been an adventure. I sent copies of the film and archives to people and communities that we had filmed with early last year and the USBs were only delivered a week or so ago! But for us one of the most important things was that people could recognise themselves and their stories in the film. In that respect it has been positive. It was important for us to get the reaction of Ruth Saovana as she had made a big decision in trusting us. She told us in an email that it was very hard for her to put it into words but that the film was both chilling and inspiring. And more importantly that 'it weaved in the spirit of Bougainville, the people and the knowledge that they are trying so very hard to protect against invaders and the greed ripping people and families apart'. Based on this we knew we could release the film and show it.

The film had its Australian premiere at the Human Rights Arts and Film Festival in Melbourne in May. Many Bougainvilleans were there and seemed proud that their stories could finally be shown on screen - and especially in Australia. Unfortunately however, showing it in Australia has been very complicated, with so far only two screenings, in Melbourne and a private one in Sydney, although we have some hopes it will get picked at upcoming festivals. It has not been shown on Australian television, while the film in New Zealand was not only shown at Academy award qualifying festival Doc Edge last year, but it was also picked up and broadcast by Māori Television. It also won many awards in countries all around the region-but Australia seems to be the hardest place to have it screened so far. It's a shame as it is an Australian story in many ways and we would love to engage with Australian audiences.

We are also thinking of ways to provide accessibility to the film and especially The Colonial Syndrome stories and archives without the need for an internet connection. We got the idea from Wikipedia, who when they launched also wondered how to make their content available to communities without internet access. The answer is small modems that can be loaded with content, and then downloaded or streamed locally by any device. It's quite simple. It's something we are thinking of, 
especially for the archives. And it's something that could also be used for further educational content that could be developed over the years in Bougainville as well.

\section{The future}

Although it may be years before another feature documentary film on this scale can be made, assistant director Nathan Matbob remains in Bougainville and can continue to document events. The situation continues to unfold and from that point of view journalism and academic research in other fields that is not dependent on corporate or government funding will be important, especially because of the lack of mainstream coverage in Australia.

A referendum on the future of Bougainville was held in November 2019, after filming was completed but before Ophir was released, with nearly 98 percent of Bougainvilleans voting for independence. This was higher than some foreign affairs commentators in Australia had been predicting but not a surprise to those involved with the documentary. The Lowy Institute in Australia for instance predicted a vote of about 75 percent (Dobell, 2019).

So far no one has been held accountable for the enormous amount of environmental damage including a billion tons of tailings that have spread 40 kilometres from the mine causing flooding and contamination. In September 2020, 56 community representatives filed a complaint with the Australian Government against Rio Tinto for environmental and human rights violations caused by its mine. The complaint, filed with the Australian OECD National Contact Point, alleges 'that the massive volume of mine waste pollution left behind by Rio Tinto's Panguna mine is putting communities' lives and livelihoods at risk, poisoning their water sources, flooding their lands and sacred sites and causing a range of health problems'. The complainants argue that Rio Tinto's failure to mitigate the risks involved in breaches of human rights and environmental standards set out in the OECD Guidelines for Multinational Enterprises, a leading international standard on responsible business conduct (HRLC, 2020a, HRLC,2020b, HRLC,2020c).

In July 2021, Rio Tinto announced that it would fund an assessment of environmental and community impacts. Assisted by a strong Human Rights Centre media release, the announcement received unusually widespread coverage in Australia and New Zealand. ABC Radio National Breakfast interviewed MP Theonila Matbob in Bougainville who spoke hopefully of 'the opening up of a new door for up to 14,000 people living in communities' along the Jaba river valley. She described living with the devastating damage as an 'everyday experience' which even with remediation will take years to fix. Asked to respond to reports that some Bougainvilleans want to reopen the Panguna mine for economic reasons, she acknowledged that although there are a few supporters 'aligned with corporate interests' who favour reopening, the community is united in wanting 
all the legacy issues of the mine remedied before any decisions about economic recovery can be made. Rio Tinto declined to be interviewed.

Ophir is produced through a partnership of filmmakers, scholars and local people. It adds to the evidence gathered by independent journalists whose work has stood out over the years. These include Ben Bohane (2013, 2019a, 2019b), David Robie (2014, 2015, 2019) and Antony Loewenstein (2018). All of these journalists demonstrate the worth of the need for direct empirical observation as a grounding for journalism research (Nash, 2016).

\section{Bougainville and Disaster Capitalism}

Loewenstein's broad ranging international reporting, which is documented on his website (antonyloewenstein.com), is marked by a consistent willingness to penetrate mainstream narratives when he finds that voices have been silenced or accounts favouring government or corporate interests uncritically promoted. His film and written work about Bougainville applies a contrasting journalistic and analytical approach that both contextualises and supports the stance taken in Ophir. Loewenstein visited Bougainville twice and stayed long enough for him to successfully negotiate with local people to visit the Panguna mine area. Like Pollet, he found that impressions gained from external media and political events about Bougainville were challenged by his reporting experiences

While Ophir conveys the feeling of being 'inside' Bougainville, Loewenstein combines a global analysis of 'disaster capitalism' with field reporting in locations where he investigated the impact of policies on the ground. To develop his global analysis of privatised aid and the domination of corporations, he drew on case studies in Haiti, Afghanistan and Bougainville.

Loewenstein, whose work is influenced by Naomi Klein (Klein, 2007) expands the conventional notion of disaster to include 'companies that entrench a crisis and then sell themselves as the only ones that can resolve it'. He is critical of the notion of 'privatised aid' that is designed to promote corporate and domestic national interests rather than the interests of local communities. Like Klein, Loewenstein 'follows the money'. His research shows that the issue of how funding sources frame research in the Pacific has continued long after Oliver was doing his covert reports in the 1960s.

Loewenstein reports that in 2013, Australia's aid agency AusAID funded a reconciliation meeting that discussed the reopening of Panguna mine. The media narrative that emerged from the meeting reported local positivity about the mine but a PNG blogger who visited Bougainville after the conference found that most people he spoke to preferred agriculture as a path to economic survival. Loewenstein quotes from a Jubilee Australia report published in 2014 that 'details the myriad of voices in Bougainville, largely ignored by the media and local government, who opposed the mine. Dozens of villagers were surveyed 
and there was near universal opposition to its reopening' (p. 159). He also draws on the research of Lasslett who interviewed eight managers who had worked for BCL between 1987 and 1992, and they all openly admitted that during the Crisis, the company provided whatever weapons and logistics the PNG military had requested. (Loewenstein, 2015, p. 160).

During his investigation, Loewenstein also revealed that the mining legislation, seen in Ophir to cause such angst among local people not previously informed about its potential impact on them, was drafted with the assistance of Australian academic, lawyer and former PNG government adviser Dr Anthony J. Regan with funding from the Australian Government. Regan is now a member of the Department of Pacific Affairs (ANU). ${ }^{1}$ Loewenstein writes,

The think-tank Australian Strategic Policy Institute released a report in 2013 that called for greater Australian aid for Bougainville, claiming civil unrest would occur without it, completely ignoring the complicity of Canberra in the province's troubles during the Crisis. Sending more AusAID money would not make locals forget who backed the polluting mine in the first place. (Loewenstein, 2015, p. 190)

While there will be debate about the political impact of these financial links, ${ }^{2}$ discussion of them is in the public interest and it is regrettable that they received little coverage in Australian mainstream media. This is not unusual however. In an interview with the authors about the media coverage of Bougainville, Loewenstein referred to the frequent use of Australian Strategic Policy Institute (ASPI) commentators as authoritative experts on international matters on the $\mathrm{ABC}$ and other media outlets that fails to make the ASPI's funding sources transparent (Loewenstein, 2021). These sources include the weapons companies Lockheed Martin and Thales, Macquarie Data Centre, the Australian Department of Foreign Affairs and Trade and overseas agencies.

\section{Conclusion}

Ophir provides a rare opportunity for audiences outside Bougainville to hear the voices of its people describing their experiences, their losses and their hopes in their own way. Although we meet some individuals in some depth, we also see scores of people discussing issues and ceremonies to grieve and commemorate their dead, many of whom simply 'disappeared'. In stark contrast to brief moments in standard television current affairs of interviewees crumbling into momentary tears before the camera moves away, we bear witness to terrible grief and trauma. At the same time, The Colonial Syndrome allows us to visit a website that documents known facts about the losses.

We cannot expect that everybody will welcome the release of Ophir. Anthony Regan, for instance, has already written a long essay favouring large scale mining 
in Bougainville in which he is scathing about 'outsiders' such as Kristian Lasslett, Jubilee Australia and even Antony Loewenstein. He accuses them of failing to be 'realistic' about the need to reopen large scale mining (Regan, 2017.)

In contemporary times, academia is contested space. The notion of the neutral detached scholar has all but been laid to rest. Most academic researchers have restricted research funding options but nevertheless do make choices. Their research is also based in different intellectual frameworks and designed to fulfil different needs and interests. Some opt to link with government and corporate sources and while not discounting their contribution, funding needs to be transparent and taken into account in assessing their work. Some will be more independent than others.

Lasslett, on the other hand, uses his academic base to provide a research and publishing home for partners. He provides an example of an academic researcher who has joined with creative practitioners and local communities to co-produce a work that has won international acclaim in documentary circles. The work is based on long standing and continuing partnerships.

This partnership has enabled a rare filmic journey into the world of Bougainvilleans. We hope that Ophir achieves the widest possible exposure throughout Oceania so that audiences can hear directly from a diverse range of Bougainvilleans and witness the devastating cultural, environmental and economic impact of the historical and contemporary policies of Rio Tinto and Australian and PNG governments.

\section{Review}

'Ophir: Bougainville's epic struggle for freedom', review by Catherine Wilson on pages 304-306.

\section{Notes}

1. 'Between 2010 and 2014, Regan was paid \$968,120 as a 'legal advisor', according to official documents.' (Loewenstein, 2015, p.162).

2. Australian academics paid $\$ 500,000$ over two years for mining work on Bougainville. (2014) PNGExposed Blog. Retrieved on September 10, 2021, from https://pngexposed. wordpress.com/2014/04/03/australian-academics-paid-500000-over-two-years-formining-work-on-bougainville/

\section{References}

AusAID fuels Bougainville mining tensions (2013, April 23). New Matilda. Retrieved on September 10, 2021, from https://newmatilda.com/2013/04/23/ausaid-fuelsbougainville-mining-tensions/

Bacon, W., \& Nash, C. (2003). How Australian media covers humanitarian issues. Australian Journalism Review. 25(2).

Berman, A., \& Pollet, O. (2017). The Panguna syndrome. [Documentary]. https://www. imdb.com/title/tt6632138/

Berman, A., \& Pollet, O. (2020). Ophir: Decolonize. Revolutionize. [Documentary]. https://www.ophir-film.com 
Berman, A., \& Pollet, O. (2020). The colonial syndrome. [Documentary] https://www. ophir-film.com/education

Berman, A., \& Pollet, O. (2020). Tears and roses. The colonial syndrome. Retrieved on September 5, 2021, from https:/www.colonialsyndrome.org/seminars/tears-roses/

Bohane, B. (2013). The black islands: Spirit and war in Melanesia. Port Vila, Vanuatu: Waka Press. https://www.benbohane.com/books/the-black-islands

Bohane, B. (2019a). Bougainville's quest for independence: A special report on the referendum. Australian Foreign Affairs, 7, 99-108.

Bohane, B. (2019b). The Bougainville referendum and beyond. The Lowy Institute. Retrieved on September 10, 2021, from https://www.lowyinstitute.org/publications/ bougainville-referendum-and-beyond

Business and Human Rights Resource Centre. (2003). Rio Tinto lawsuit (re Papua New Guinea). Retrieved on September 10, 2021, from https://www.business-humanrights. org/en/latest-news/rio-tinto-lawsuit-re-papua-new-guinea/

Cass, P. (2014). Press, politics and people in Papua New Guinea 1950-75. Auckland, NZ: Unitec Press. Retrieved on September 16, 2021, from http://www.unitec.ac.nz/ epress/index.php/press-politics-and-people-in-papua-new-guinea-1950-1975

Cochrane, G. (2017). Anthropology in the mining industry: Community relations after Bougainville's civil war. Palgrave.

Damadi, M. (2020, February 17). Ophir: The story of Bougainville. Pacific Mornings. Radio Australia. Retrieved on September 10, 2021, from https://www.abc.net.au/ radio-australia/programs/pacificmornings/ophir-the-story-of-bougainville/11970862

Denoon, D. (2000). Getting under the skin: The Bougainville copper agreement and the creation of the Panguna mine. Melbourne,VIC: Melbourne University Press.

Dinnen, S., Okazaki, A., \& Walton, G. (2020). Nation making and nation breaking in the Pacific islands: the case of Papua New Guinea. Retrieved on September 5, 2021, from https://gjia.georgetown.edu/2020/05/05/nation-making-and-nation-breaking-inthe-pacific-islands-the-case-of-papua-new-guinea/

Dobell, G. (2019). Bougainville’s ‘Melanesian way' beyond the referendum. The Strategist. ASPI. Retrieved on September, 10, 2021, from https:/www.aspistrategist.org. au/bougainvilles-melanesian-way-beyond-the-referendum/.

Duffield, L. (2020). Forgetting PNG? Australian media coverage of Papua New Guinea. Pacific Journalism Review : Te Koakoa, 26(1), 178-193. https://doi.org/10.24135/ pjr.v26i1.1069

Garrett, J. (2013, March 7). Bougainville to pass world first mining law. Pacific Beat. Australian Broadcasting Corporation. Retrieved on September 6, 2021, from https:// www.abc.net.au/news/2013-03-07/bougainville-mining-law-a-world-first/4559170

Graue, C. (2018, October 19) Has the Bougainville Referendum been overshadowed by APEC? Interview with Dr Ruth Saovana-Spriggs. Pacific Beat. Australian Broadcasting Corporation. Retrieved on September 9, 2021, from https://www.abc.net.au/ radio-australia/programs/pacificbeat/bougainville-ref/10395008

Griffin, J. (1989, March 30). Bougainville_-a people apart. The Australian Financial Review.

Human Rights Law Centre. (2020). Bougainville communities file human rights complaint against Rio Tinto for impacts of mine waste pollution. Retrieved on September 12, 2021, from https://www.hrlc.org.au/news/2020/9/28/bougainville-communities-filehuman-rights-complaint-rio-tinto

Human Rights Law Centre. (2020). Complaint against Rio Tinto. Retrieved on September 12, 2021, from https://static1.squarespace.com/static/580025f66b8f5b2dabbe4291/t/5f 
71485babd4ac5b16bff4d9/1601259616769/OECD+complaint+Bougainville+Final.pdf Human Rights Law Centre. (2020). After the mine-living with Rio Tinto's deadly legacy. Retrieved on September 12, 2021, from https://static1.squarespace.com/ static/580025f66b8f5b2dabbe4291/t/5e7d7cce47c7f816da86005f/1585282297310/ AfterTheMineRioTintoDeadlyLegacy.pdf

Jubilee Australia Research Centre. (2014). Voices of Bougainville. Retrieved on September 5, 2021, from https://www.jubileeaustralia.org/storage/app/uploads/public/5 $\mathrm{fb} / 8 \mathrm{c} 6 / 580 / 5 \mathrm{fb} 8 \mathrm{c} 65806278200473384$.pdf

Jubilee Australia Research Centre. (2020). Blank cheque: The risk of proposed amendments to Bougainville's mining act. Retrieved on September 5, 2021, from https://www.jubileeaustralia.org/storage/app/uploads/public/5fb/8c5/f98/5fb8c5f98261e826474711.pdf

Klein, N. (2007). The shock doctrine: The rise of disaster capitalism. Toronto, Canada: Knopf.

Lasslett, K. (2013). Beyond state-fetishism: Developing a theoretical programme for state crime studies. Revista Crítica Penal y Poder, 5, 115-137.

Lasslett, K. (2014). State crime on the margins of empire: Rio Tinto, the war on Bougainville and resistance to mining. Sydney, NSW: Pluto Press.

Loewenstein, A. (2013). Profits of doom: How vulture capitalism is swallowing the world. Melbourne, VIC: Melbourne University Publishing.

Loewenstein, A. (2015). Disaster capitalism: making a killing out of catastrophe. London, UK: Verso Books.

Loewenstein, A., \& Neureiter, T. (2018). Disaster capitalism. [Documentary]. https:// disastercapitalismfilm.com

Loewenstein, A. (2021, August 30). Interview with authors.

Lopez, B. (2020a). \#I'llridewithyou, West Papua. Earshot. ABC Radio National. Retrieved on September 10, 2021, from https://www.abc.net.au/radionational/programs/ earshot/iillridewithyou-west-papua/12005696

Lopez, B. (2020). FRONTLINE: Reversing silences in West Papua: Interdisciplinary research and (audio) documentary. Pacific Journalism Review: Te Koakoa, 26(1), 200-225. https://doi.org/10.24135/pjr.v26i1.1097

Lopez, B. (2020). The Indonesian women speaking out about West Papua-whatever the cost. Australian Broadcasting Corporation. Retrieved from https://www.abc. net.au/news/2020-03-23/illridewithyou-indonesians-cost-of-talking-about-westpapua/12049936.

Lorne, D. (2013, July 1). Rio Tinto wins case. PNG Post-Courier.

Nash, C. (2016). What is journalism? The art and politics of a rupture. London, UK: Palgrave McMillan.

Oliver, D. (1968). Some social-relational aspects of CRA copper mining on Bougainville, a confidential report to management. The Colonial Syndrome. Retrieved on September 5, 2021, from https://www.colonialsyndrome.org/files/series-2/9-oliver1968-internal-report.pdf

Oliver, D. L., \& Oliver, D. L. (1991). Black islanders : a personal perspective of Bougainville 1937-1991. [Revised ed.]. Honolulu, HA: University of Hawai'i Press.

Orsag, T. (2020). Bougainville's independence vote: Australia's headache. Overland. Retrieved on September 5, 2021, from https://overland.org.au/2020/03/bougainvillesindependence-vote-australias-headache/

Pollet, O. (2013) Canning paradise. [Documentary] https://www.youtube.com/ watch? $\mathrm{v}=\mathrm{gVp} 9 \mathrm{qVexHug}$

Senate Foreign Affairs, Defence and Trade Legislation Committee (2013, November 21). 
Supplementary budget estimates: Questions in writing (pp. 541-553). Retrieved on September 10, 2021, from http://www.aph.gov.au/ /media/Estimates/Live/fadt_ctte/ estimates/sup_1314/dfat/dfatqonanswers.pdf

Regan, A. J. (2017). Bougainville: Origins of the conflict, and debating the future of large-scale mining. In C. Filer and P.Y. Le Meur, (Eds.), Large-scale mines and local-level politics: between New Caledonia and Papua New Guinea (pp. 353 - 414). Canberra, ACT: ANU Press.

Robie, D. (2004). REVIEW: Bougainville's inspiring tribute to survival by women of peace: Review of ... As mothers of the land: The birth of the Bougainville women for peace and freedom, edited by Josephine Tankunani Sirivi and Marilyn Taleo Havini. Pacific Journalism Review : Te Koakoa, 10(1), 224-228. https://doi.org/10.24135/ pjr.v10i1.798

Robie, D. (2014 ). Don't spoil my beautiful face: Media, mayhem and human rights in the Pacific. Auckland, NZ: Little Island Press.

Robie, D. (2015). New Dawn FM and the Bougainville mining lobby machine? Cafe Pacific. Retrieved on September 8, 2021, from https://cafepacific.blogspot.com/2015/04/ new-dawn-fm-and-bougainville-mining.html

Robie, D. (2019). REVIEW: How soldier guitars, culture and faith paved way for Bougainville's peace. Pacific Journalism Review : Te Koakoa, 25(1\&2), 303-306. https:// doi.org/10.24135/pjr.v25iland2.502

Seke, S., \& Wayne, H. (2021). Wantok. ABC Radio Australia. Retrieved on September 12, 2021, from https://www.abc.net.au/radio-australia/programs/wantok/wantok/13324894

Shearn, T., \& Pollet, O. (2014). When we were Hela. [Documentary]. https://www. youtube.com/watch? $\mathrm{v}=\mathrm{m} 3$ YOmjAlB $7 \mathrm{k}$

Tahun, M. (1998). An anthology of crisis poetry from Bougainville. [Vol 1.]. Port Moresby, PNG: UPNG Press.

Trouillot, M-R. (2015). Silencing the past: power and the production of history. Boston, MS: Beacon Press.

Watkins, E. (2019, April 26). Australian media's coverage of the Pacific has almost completely disappeared. Crikey. Retrieved on September 6, 2021, from https://www. crikey.com.au/2019/04/26/australian-media-pacfiic/

Wilson, C. (2011). Papua New Guinea: Women call the shots on mega copper mine. Global Issues. Retrieved on September 11, 2021 from https://www.globalissues.org/ news/2011/10/16/11540

Wendy Bacon is an independent researcher and journalist who publishes in the fields of climate change, media, journalism, local politics, gender, environment and urban planning. She publishes on her blog wendybacon.com. She was previously the director of the Australian Centre for Independent Journalism (ACIJ) and a professor of journalism at the University of Technology Sydney (UTS). wendybacon1@gmail.com

Nicole Gooch is an independent journalist and a PhD candidate at the University of Technology Sydney (UTS), researching decolonisation and mining in Kanaky New Caledonia, and a member of the Climate Justice Research Centre (UTS). nicolesgooch@gmail.com 